\title{
Macroinvertebrate colonisation associated with native and invasive leaf litter decomposition
}

\author{
Thendo Mutshekwa ${ }^{1}$, Ross N. Cuthbert ${ }^{2, *}$, Ryan J. Wasserman ${ }^{3,4}$, Florence M. Murungweni ${ }^{1}$ \\ and Tatenda Dalu ${ }^{1,5, *}$ \\ ${ }^{1}$ Aquatic Systems Research Group, Department of Ecology and Resource Management, University of Venda, Thohoyandou 0950, \\ South Africa \\ 2 GEOMAR, Helmholtz-Zentrum für Ozeanforschung Kiel, 24105 Kiel, Germany \\ ${ }^{3}$ Department of Biological Sciences and Biotechnology, Botswana International University of Science and Technology, Palapye, \\ Botswana \\ ${ }^{4}$ Department of Zoology and Entomology, Rhodes University, Makhanda 6140, South Africa \\ ${ }^{5}$ Stellenbosch Institute for Advanced Study, Stellenbosch 7600, South Africa
}

Received: 22 January 2020 / Accepted: 9 June 2020

\begin{abstract}
Lake and reservoir ecosystems are regarded as heterotrophic detritus-based habitats which are dependent on both autochthonous and allochthonous organic matter for the majority of energy inputs. In particular, allochthonous detritus is in particular important for the trophic dynamics of microbial organisms, macroinvertebrates and benthic plants in freshwaters. Here, we assess macroinvertebrate colonisation, and quantify decomposition rates, of leaf litter from species of native and invasive plants in a small agricultural reservoir. Native fig Ficus sycomorus and silver cluster-leaf Terminalia sericea were compared to invasive tickberry Lantana camara and guava Psidium guajava, whereby macroinvertebrate colonisation was assessed over time. Leaf treatments had a significant, group-specific effect on abundances and composition among focal macroinvertebrates. Invasive leaves reduced Physidae and Oligochaeta abundances, yet Ostracoda were significantly more abundant in the presence of invasive $P$. guajava. Chironomidae relative abundances increased under invasive L. camara treatments, whilst differences among leaf treatment effects on Coenogrionidae abundances were not statistically clear. In turn, macroinvertebrate diversity did not differ significantly among plant treatment groups. The decomposition rate of the leaf litter demonstrated differences among the species, following a decreasing order of $L$. camara $>F$. sycomorus $>$. sericea $>$ P. guajava. The study results highlight that leaf litter species identity among invasive and native plants plays an important role in the colonisation of macroinvertebrates in small reservoirs, thereby differentially supporting aquatic environments and food webs. However, differences were not uniform across invader-native groupings. Nonetheless, certain invasive leaf litter decomposes faster than native litter, with possible implications for broader nutrient dynamics and subsequent community composition.
\end{abstract}

Keywords: Macroinvertebrates / allochthonous / leaf litter decomposition / native / invasive

Résumé - Colonisation de macro-invertébrés associée à la décomposition de la litière de feuilles d'indigènes et d'envahissantes. Les écosystèmes des lacs et des réservoirs sont considérés comme des habitats hétérotrophes à base de détritus qui dépendent à la fois des matières organiques autochtones et allochtones pour la majorité des apports énergétiques. En particulier, les détritus allochtones sont extrêmement importants pour la dynamique trophique des organismes microbiens, des macroinvertébrés et des plantes benthiques d'eau douce. Ici, nous évaluons la colonisation des macroinvertébrés et quantifions les taux de décomposition de la litière de feuilles de quatre espèces de plantes indigènes et envahissantes dans un petit réservoir agricole. Le figuier indigène Ficus sycomorus et la Terminalia sericea à feuilles argentées ont été comparés au mÛrier envahissant Lantana camara et à la goyave Psidium guajava, ce qui a permis d'évaluer la colonisation des macroinvertébrés dans le temps. Les traitements foliaires ont eu un effet significatif, spécifique au groupe, sur l'abondance et la composition des macroinvertébrés focaux. Les

\footnotetext{
*Corresponding author: rossnoelcuthbert@gmail.com (RNC); dalutatenda@yahoo.co.uk (TD)
} 
feuilles d'envahissantes ont réduit l'abondance des Physidés et des Oligochètes, alors que les Ostracodes étaient significativement plus abondants en présence de $P$. guajava envahissante. L'abondance relative des Chironomidae a augmenté en présence de L. camara, tandis que les différences entre les origines foliaires sur l'abondance des Coenogrionidae n'étaient pas statistiquement claires. De même, la diversité des macroinvertébrés n'a pas différé de manière significative entre les groupes de plantes. Le taux de décomposition de la litière de feuilles a montré des différences entre les espèces, suivant un ordre décroissant de $L$. camara $>$ F. sycomorus $>T$. sericea $>$ P. guajava. Les résultats de l'étude soulignent que l'identité des espèces de la litière parmi les plantes envahissantes et indigènes joue un rôle important dans la colonisation des macroinvertébrés dans les petits réservoirs, soutenant ainsi de manière différenciée les environnements aquatiques et les réseaux alimentaires. Cependant, les différences n'étaient pas uniformes entre les groupes d'espèces indigènes et envahissantes. Néanmoins, certaines litières de feuilles envahissantes se décomposent plus rapidement que les litières indigènes, ce qui peut avoir des conséquences sur la dynamique des nutriments en général et sur la composition des communautés qui en résultent.

Mots-clés : Macroinvertébrés / allochtone / décomposition de litière / indigène / invasion

\section{Introduction}

Leaf litter decomposition is a key ecosystem process that greatly influences the formation of soil organic matter, the release of nutrients for plants and microorganisms, and carbon dioxide $\left(\mathrm{CO}_{2}\right)$ fluxes in terrestrial and aquatic ecosystems (Jeyanny et al., 2015). The litter decomposition rate is controlled by intrinsic factors, for instance chemical and physical properties of leaf litter, and by extrinsic abiotic and biotic factors (Chen et al., 2019). Biotic factors include heterotrophic microorganisms (e.g. fungi and bacteria) and macroorganisms (e.g. macroinvertebrates) that break down leaves, with these processes also strongly influenced by environmental factors such as temperature (Chen et al., 2019). As such, the leaf litter decomposition process is comprised of three phases: (i) leaching of components from the leaf litter, followed by (ii) conditioning by microorganisms and finally, (iii) fragmentation and consumption by macroorganisms (Webster \& Benfield, 1986). Allochthonous plant material inputs into lakes and reservoirs are subject to the same decomposition processes. When terrestrial plant litter enters the aquatic system, it starts to decompose and rapidly loses mass due to the leaching process, with up to $30 \%$ lost within the first $24 \mathrm{hrs}$ of decomposition (Petersen \& Cummins, 1974).

Aquatic invertebrates feeding on leaf litter are dominated by shredders, and their densities may be correlated with the spatial and temporal accumulation of organic matter in lakes and reservoirs (Pope et al., 1999). Accordingly, community composition of above-ground plants may exert marked influence on aquatic invertebrate communities. The invertebrates that feed on organic matter incorporate derived nutrients in secondary production, further contributing to temporal leaf fragmentation processes (Graça, 2001). However, not all nutrients are directly incorporated into secondary productivity of macroinvertebrates, with much content being made available for other biotic and abiotic processes (Wallace et al., 2015). Sometimes, the leaf litter which accumulates generally results in an increase in the nitrogen content (Suberkropp \& Chauvet, 1995). Moreover, leaves start to undergo loss of mass at a rate proportional to invertebrate colonisation (Suberkropp \& Chauvet, 1995). Further, high decomposition rates have, in several studies, been positively correlated with species richness
(Duarte et al., 2006; Dangles \& Malmqvist, 2004). As such, community dynamics of colonising macroinvertebrates are important for nutrient cycling processes. Whilst macroinvertebrate communities in lakes and reservoirs rely on input of terrestrial litter as an energy source, terrestrial landscapes are changing due to invasive species, with the plant communities in riparian zones being no exception. The invasion process is regarded as one of the major drivers of plant community shifts, whereby native plants may be outcompeted and subsequently replaced by non-native species (Wallace, 2012). While these terrestrial processes and their implications have been explored extensively (Alonso et al., 2010; MedinaVillar et al., 2015; Ferreira et al., 2016), the implications of cross-ecosystem subsidies from invasive species in riparian zones for aquatic macroinvertebrate communities in the global south lack quantification.

In the present study, we thus assess macroinvertebrate colonisation and quantify leaf litter decomposition rates over time among two native (fig Ficus sycomorus, silver clusterleaf Terminalia sericea) and two invasive (lantana/tickberry Lantana camara, guava Psidium guajava) terrestrial plants which are known to co-exist in around certain aquatic ecosystems. The deciduous exotic shrub L. camara and semideciduous tree $P$. guajava are native to tropical central and southern America and are known to have a substantial negative impact on native plant species through competition and replacement (Richardson and Van Wilgen, 2004; Vardien et al., 2012; Urquía et al., 2019). Both species are recognised as invasive in South Africa (Henderson, 2007; Gaertner et al., 2016). These invasive species were selected because they have been reported to spread fast within riparian zones, in turn threatening the abundance and diversity of native plant species and community stability of aquatic ecosystems. Ranaswanu and Sukumar (2014) indicated that the highest L. camara abundances are found in proximity to aquatic ecosystems, where their leaf litter may accrue. Dominant native plant species were selected for comparison. The semi-deciduous tree $F$. sycomorus and deciduous tree $T$. sericea are both native to southern Africa and both species are often naturally found in riparian zones of aquatic ecosystems (Henderson, 2007; Pothasin et al., 2014; Sunil et al., 2016). We hypothesised that: (i) native $F$. sycomorus and $T$. sericea will support a more abundant and diverse invertebrate community compared to invasive L. camara and P. guajava; and (ii) native plant leaf 
litter will decompose faster compared to that from invasive plants. These hypotheses are based on previous study which have demonstrated slow decomposition rates in invasive species compared to natives, driven potentially by greater lignin content in invasive species' leaves (Godoy et al., 2010).

\section{Materials and methods}

\subsection{Study area}

The study was conducted within the Levubu River catchment $(-23.091403 \mathrm{~S}, 30.313697 \mathrm{E})$ which falls under Vhembe district, Limpopo, situated in a sub-tropical fruit farming area in the Makhado Municipality, South Africa. The catchment contributes to the Limpopo system, which flows into Mozambique. The Luvuvhu River and a portion of its tributaries, i.e. Mutale and Mutshindudi Rivers, rise in the Soutpansberg Mountains. The Luvuvhu River flows to about $200 \mathrm{~km}$ between various ranges of landscape before joining the Limpopo River that is near Kruger National Park. The climatic conditions vary considerably within the Levubu River catchment. The mean annual temperature ranges from approximately $18-35^{\circ} \mathrm{C}$, with an average of about $25.5^{\circ} \mathrm{C}$ (SA Weather Service, 2018). Maximum temperatures are experienced in December, January, and February, and minimum temperatures occur on average in July. Rainfall is seasonal and occurs mainly during the summer months (i.e. October to March). In the Luvuvhu River catchment, the mean annual rainfall is $608 \mathrm{~mm}$ (SA Weather Service, 2018). The present study was carried out in winter (22nd May to 19th July 2019). One small reservoir which experienced relatively little human interference was selected along the Luvuvhu River catchment middle reaches.

\subsection{Experimental design}

Our experiment was conducted in situ through the use of a meshed bag technique at a time of low rainfall to mitigate risk of disturbance from flooding. Fresh plant leaves of invasive (i.e. L. camara, P. guajava) and native (i.e. F. sycomorus, T. sericea) were collected in November 2018 by hand from trees along Mvudi River riparian zone $\left(22^{\circ} 58.967^{\prime} \mathrm{S}\right.$ $30^{\circ} 26.840^{\prime} \mathrm{E}$ ) in Thohoyandou, Limpopo province, South Africa, before being air dried at room temperature (range 27$30^{\circ} \mathrm{C}$ ). After drying, $3.0 \pm 0.1 \mathrm{~g}$ of the dried material for each species was weighed and added into each of $5 \mathrm{~mm}$ coarse-mesh bags, with 80 bags used in total (i.e. 4 species, $\times 4$ temporal sampling events, $\times 5$ replicates each). The coarse-mesh bags were sealed and attached with zip ties. According to plant species, each bag was tagged with different plastic colours $\left(\sim 0.25 \mathrm{~cm}^{2}\right)$ for identification during retrieval. All bags were deployed on Day 0 (22 May 2019) and were spaced $1 \mathrm{~m}$ apart in the field, with bag retrieval taking place after 14, 28, 42 and 56 days. The bags were randomly attached to ropes, tied with weights and attached to an abandoned boat for anchorage. Bags were randomised and separated to avoid spatial confounds. The water depth ranged between $0.4 \mathrm{~m}$ and $0.6 \mathrm{~m}$, and the bags were placed about $1 \mathrm{~m}$ away from the shoreline.

To quantify leaf leaching, in a separate experiment, 20 additional bags (i.e. $\times 4$ species, and $\times 5$ replicates each) were deployed in buckets with filtered ( $63 \mu \mathrm{m}$ mesh) reservoir water in the laboratory on Day 0 and removed on Day 2, to examine decomposition within $48 \mathrm{hrs}$ without macroinvertebrates.

\subsection{Sampling}

On each sampling event, conductivity $\left(\mu \mathrm{S} \mathrm{cm}^{-1}\right)$, total dissolved solids $\left(\mathrm{mg} \mathrm{L}^{-1}\right), \mathrm{pH}$, temperature $\left({ }^{\circ} \mathrm{C}\right)$, sodium chloride $(\mathrm{ppm})$, oxidation reduction potential $(\mathrm{mV})$ and resistivity (Ohms $-\Omega)$ ) were measured using a portable handheld multi-parameter Cyberscan Series Waterproof Portable Meter (Eutech Instruments). Twenty bags were retrieved during each sampling day, with only 2 replicates each being recovered for day 56 (i.e. $\times 4$ species, and $\times 3$ replicates each were lost). Once removed from the water, the bags were immediately placed into polyethylene zip bags to prevent loss of macroinvertebrates and decomposed leaves. In the laboratory, the bags were emptied into trays with a small amount of distilled water, and the macroinvertebrates were identified to family level and enumerated as absolute and relative abundances (\%). Each replicate was preserved in $50 \mathrm{~mL}$ containers with $70 \%$ ethanol. The macroinvertebrate taxa were further separated into functional feeding groups (i.e. collector-filterer, collector-gatherer, scraper, shredder, predator) according to Cummins et al. (2005) and Merritt et al. (2008). Decomposed leaves were then rinsed with sterilised distilled water to remove sediments, oven-dried at $60^{\circ} \mathrm{C}$ for $48 \mathrm{hrs}$ and weighed.

\subsection{Statistical analyses}

All statistical analyses were performed using R v3.4.2 (R Development Core Team, 2018). Differences in environmental parameters across sampling events were analysed using Kruskal-Wallis tests. The effects of leaf treatment and observation week, and their interaction, on the absolute abundances of each group of invertebrates were analysed using a negative binomial generalised linear mixed model, with experimental replicates as a random effect (intercept) to account for repeated measures of invertebrate groups. A Poisson error distribution was used initially, with the resulting model checked for overdispersion and zero inflation via examination of fitted residuals against model simulations (Hartig, 2018). Separately, binomial generalised linear mixed models were used to examine the effects of leaf treatment, macroinvertebrate group and observation week, and their interactions, on relative abundances. To account for repeated measures of invertebrates within each mesh bag, a replicatelevel random effect was again included (intercept). The final sets of observations were excluded from analyses as we lost 3 of the 5 replicates in the field (see before). Type III analyses of deviance were used to infer effect sizes. Post-hoc pairwise comparisons were performed using Tukey tests via estimated marginal means (Lenth, 2019).

Richness within each experimental replicate over time was calculated using Menhinick's diversity index $(D)$, which is the number of taxa divided by the square-rooted sample size $(D=s / \sqrt{ } N)$, where " $s$ " corresponds to the number of species groups, and " $N$ " the total number of organisms within a sample (Whittaker, 1977). Resulting indices were $\log _{10}$ transformed and analysed using linear models as a function of leaf treatment 
T. Mutshekwa et al.: Knowl. Manag. Aquat. Ecosyst. 2020, 421, 32

Table 1. Descriptive environmental parameters (mean $\pm \mathrm{SD}$ ) measured within the Luvuvhu River farm reservoir.

\begin{tabular}{|c|c|c|c|c|c|c|c|c|c|}
\hline \multirow[t]{2}{*}{ Parameters } & \multirow[t]{2}{*}{ Units } & \multicolumn{2}{|c|}{ Day 14} & \multicolumn{2}{|c|}{ Day 28} & \multicolumn{2}{|c|}{ Day 42} & \multicolumn{2}{|c|}{ Day 56} \\
\hline & & Mean & $\overline{\mathrm{SD}}$ & Mean & $\overline{\mathrm{SD}}$ & Mean & $\mathrm{SD}$ & Mean & $\overline{\mathrm{SD}}$ \\
\hline Conductivity & $\mu \mathrm{S} \mathrm{cm}-1$ & 561.5 & 2.6 & 549.7 & 0.3 & 561.2 & 1.2 & 558.8 & 0.3 \\
\hline Total dissolved solids & $\mathrm{mg} \mathrm{L}^{-1}$ & 192.4 & 0.6 & 180.4 & 0 & 176.6 & 1.3 & 177.5 & 1.4 \\
\hline $\mathrm{pH}$ & & 7.4 & 0.1 & 7.7 & 0 & 7.9 & 0 & 7.2 & 0 \\
\hline Temperature & ${ }^{\circ} \mathrm{C}$ & 16.8 & 0 & 16 & 0.1 & 15.2 & 0 & 16.1 & 0.1 \\
\hline Salinity & ppm & 279.8 & 4.9 & 265.4 & 2.1 & 269 & 1.4 & 269.3 & 0.7 \\
\hline Oxidation reduction potential & $\mathrm{mV}$ & -36.2 & 3.9 & -43.6 & 0.3 & -49.5 & 0.8 & -50 & 0.1 \\
\hline Resistivity & $\Omega$ & 2.7 & 0 & 2.8 & 0 & 2.8 & 0 & 2.8 & 0 \\
\hline
\end{tabular}

and observation week (as above), with residuals checked for normality and homoscedasticity via diagnostic plotting (Zuur et al., 2010).

Decomposition rates of each leaf type were estimated using the decomposition coefficient $(k)$ resulting from the exponential decay model (Olson, 1963): $Y_{t}=Y_{0} \cdot e^{-k t}$, where $Y_{0}$ and $Y_{t}$ are the initial and final dry mass of leaves $(\mathrm{g})$ after time $t$, respectively, $t$ is time in days, $e$ is the natural logarithm and $k$ is the decomposition rate coefficient. According to Petersen and Cummins (1974), based on the decomposition rate coefficient, leaves can be classified as "fast" $(k>0.01)$, "medium" $(k=0.005-0.01)$ or "slow" $(k<0.005)$ decomposers. Differences in end leaf weights were also analysed using linear models as a function of leaf treatment (see before).

\section{Results}

Table 1 summarises the mean values of environmental parameters within Levubu River farm reservoir for the study period. Conductivity varied between $549.7 \mu \mathrm{S} \mathrm{cm}^{-1}$ after 28 days of incubation to $561.5 \mu \mathrm{S} \mathrm{cm}^{-1}$ after 42 days. High total dissolved solids of $192.4 \mathrm{mg} \mathrm{L}^{-1}$ were measured at day 14 and tended to reduce over time, with low values of $176.6 \mathrm{mg} \mathrm{L}^{-1}$ at day 42 . The $\mathrm{pH}$ was slightly alkaline ranging from 7.2 (day 56) to 7.9 (day 42) (Tab. 1). The water temperature and salinity were around $16{ }^{\circ} \mathrm{C}$ and $270 \mathrm{ppm}$, respectively, throughout the study period (Tab. 1). Redox potential (ORP) observed was $-36.2 \mathrm{mV}$ after 14 days of incubation, decreasing progressively to the end of the experiment to $-50 \mathrm{mV}$. Resistivity was relatively similar through time, ranging from 2.7 to $2.8 \Omega$. No significant differences $(p>0.05)$ in all environmental parameters were observed across the sampling events.

The collector-gatherer Oligochaeta, collector-filterer Ostracoda, shredder Chironomidae, scraper Physidae and predator Coenagrionidae were identified within the leaf treatments. Absolute abundances of macroinvertebrate groups differed significantly among plant treatments and over time owing to significant two-way interactions (Tab. 2; Fig. 1). Chironomid raw abundances decreased over time and did not significantly differ among leaf treatments, whilst Oligochaeta undulated and were significantly more abundant in native $F$. sycomorus compared to L. camara $(p=0.01)$, and T. sericea compared to both invasive species (both $p \leq 0.01$ ) (Fig. 1). In turn, Ostracoda increased over the first three sampling events
Table 2. Zero-inflated negative binomial generalised linear mixed model results considering absolute macroinvertebrate abundances as a function of plant treatment (Plant), macroinvertebrate group (Group) and observation week (Week), and their two- and three-way interactions. Significant $p$-values are emboldened.

\begin{tabular}{llll}
\hline Predictor & $\mathrm{df}$ & $\chi^{2}$-value & $p$-value \\
\hline Plant & 3 & 2.43 & 0.49 \\
Group & 4 & 104.71 & $<\mathbf{0 . 0 0 1}$ \\
Week & 1 & 2.14 & 0.14 \\
Plant:Group & 12 & 24.16 & $\mathbf{0 . 0 2}$ \\
Plant:Week & 3 & 2.40 & 0.49 \\
Group:Week & 4 & 74.99 & $<\mathbf{0 . 0 0 1}$ \\
Plant:Group:Week & 12 & 12.44 & 0.41 \\
\hline
\end{tabular}

and were significantly most abundant in P. guajava treatments compared to all other plant species (all $p<0.01$ ). Coenogrionidae abundances tended to decrease and did not differ significantly among plant treatments, whilst Physidae abundances undulated and were significantly more abundant in native $F$. sycomorus litter compared to both invasive species (both $p \leq 0.01$ ). Other pairwise comparisons were not statistically different (all $p>0.05$ ) (Fig. 1).

Proportional abundances among macroinvertebrate groups differed significantly according to plant leaf treatment and observation week, owing to a significantly three-way interaction term (Tab. 3). Chironomid relative abundances tended to decrease over time (Fig. 2) and were significantly greater under invasive $L$. camara treatments relative to all other plants overall $(p<0.01)$, and $F$. sycomorus compared to $T$. sericea $(p=0.02)$. Other paired comparisons were not significant (both $p>0.05$ ). Conversely, Oligochaeta relative abundances were significantly greater following native $T$. sericea treatments compared to all other plant groups (all $p \leq$ $0.001)$, and $F$. sycomorus compared to P. guajava $(p=0.03)$, whilst all other groups were more similar (all $p>0.05$ ). Oligochaeta abundances generally became relatively greater over the monitoring period (Fig. 2). Ostracod relative abundances increased over time and were significantly increased in the invasive $P$. guajava treatment compared to all other plant litter types (all $p<0.001$ ), which were, in turn, not significantly different (all $p>0.05$ ) (Fig. 2). Relative abundance contributions from Coenogrionidae did not differ significantly among plant treatments (all $p>0.05$ ) and 

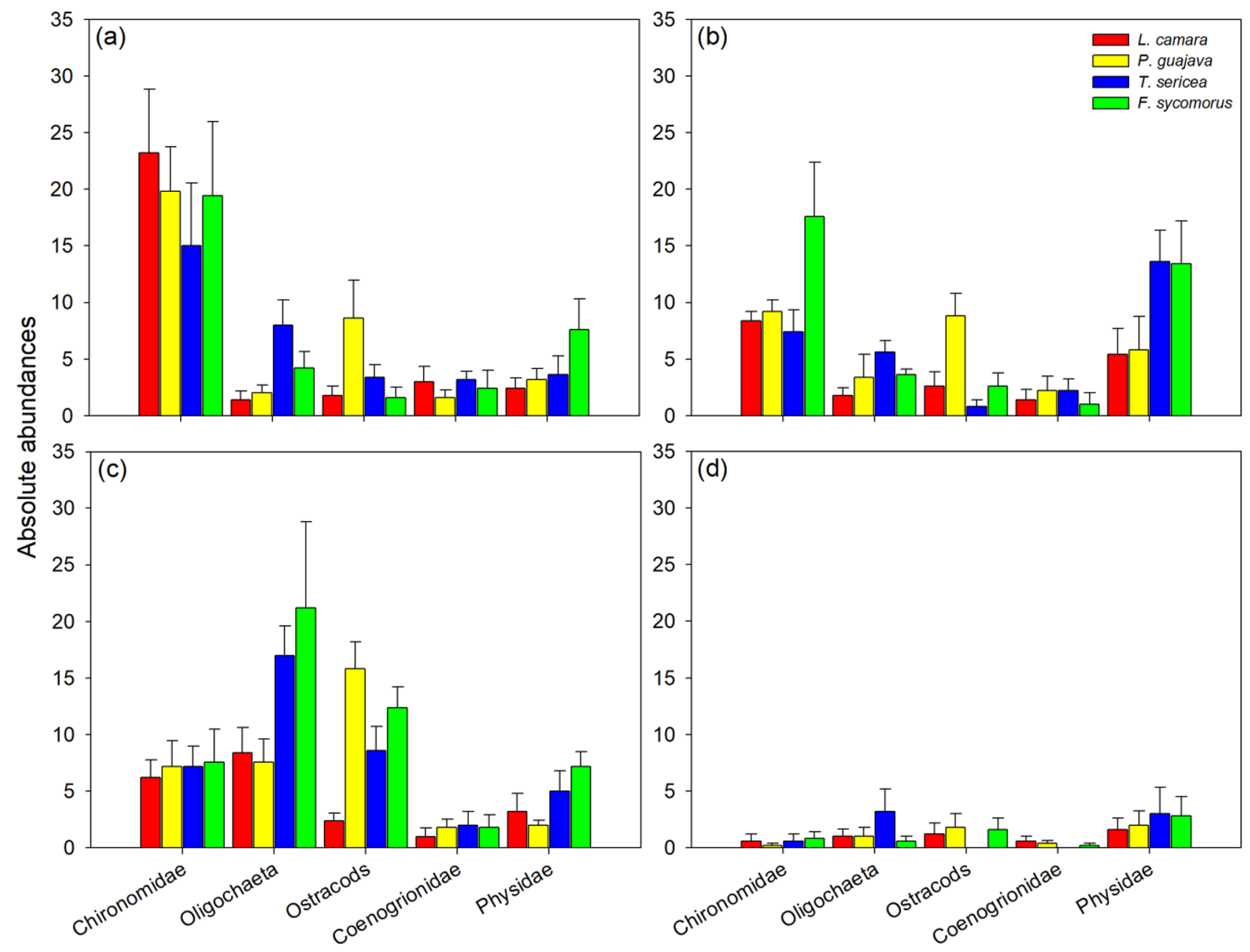

Family taxa

Fig. 1. The colonisation of macroinvertebrates (absolute abundance \pm SE) at days 14 (a), 28 (b), 42 (c) and 56 (d) on invasive $L$. camara (red), invasive $P$. guajava (yellow), native $T$. sericea (blue) and native $F$. sycomorus (green).

Table 3. Binomial generalised linear mixed model results considering relative macroinvertebrate abundances as a function of plant treatment (Plant), macroinvertebrate group (Group) and observation week (Week), and their two- and three-way interactions. Significant $p$ values are emboldened.

\begin{tabular}{llll}
\hline Predictor & $\mathrm{df}$ & $\chi^{2}$-value & $p$-value \\
\hline Plant & 3 & 4.61 & 0.20 \\
Group & 4 & 556.25 & $<\mathbf{0 . 0 0 1}$ \\
Week & 1 & 5.64 & $<\mathbf{0 . 0 0 1}$ \\
Plant:Group & 12 & 93.99 & $<\mathbf{0 . 0 0 1}$ \\
Plant:Week & 3 & 2.27 & 0.52 \\
Group:Week & 4 & 362.27 & $<\mathbf{0 . 0 0 1}$ \\
Plant:Group:Week & 12 & 41.54 & $<\mathbf{0 . 0 0 1}$ \\
\hline
\end{tabular}

reduced temporally (Fig. 2). Invasive $P$. guajava exhibited significantly reduced relative abundances of Physidae compared to either native plants (both $p<0.001$ ), and $L$. camara reduced abundances relative to $F$. sycomorus $(p=0.02)$; other plant input types were more similar (all $p>0.05)$. This asymmetric response among macroinvertebrate groups is further reflected by a lack of statistically-clear difference in species group diversity among leaf treatments $\left(F_{3,52}=1.99 p=0.13\right)$, observation weeks $\left(F_{1,52}=0.36\right.$, $p=0.55)$ or their interaction $\left(F_{3,52}=0.60, p=0.62\right)$.

Daily decay rates differed significantly among leaf species (Fig. 3). Invasive L. camara had the highest decay rates $[0.072$ (day 14) to 0.021 (day 56)], which indicates faster decomposition rate $(k>0.01)$ in relation to other leaf types. Native F. sycomorus had slightly greater decays rates [0.035 (day 14) to 0.011 (day 56)] than native T. sericea [0.018 (day 14) to 0.007 (day 56)] and invasive P. guajava [0.017 (day 14) to 0.005 (day 56)], with L. camara having the highest throughout sampling days. Terminalia sericea and invasive $P$. guajava decomposed slower (both $k<0.005$ ).

In terms of decomposition during the leaching process, leaf weights after $48 \mathrm{hrs}$ differed significantly according to species $\left(F_{3,12}=12.72, p<0.001\right)$. Invasive $L$. camara and native $F$. sycomorus weights were reduced most, and significantly compared to native $T$. sericea and invasive $P$. guajava (all $p<0.01$; Fig. 4). 


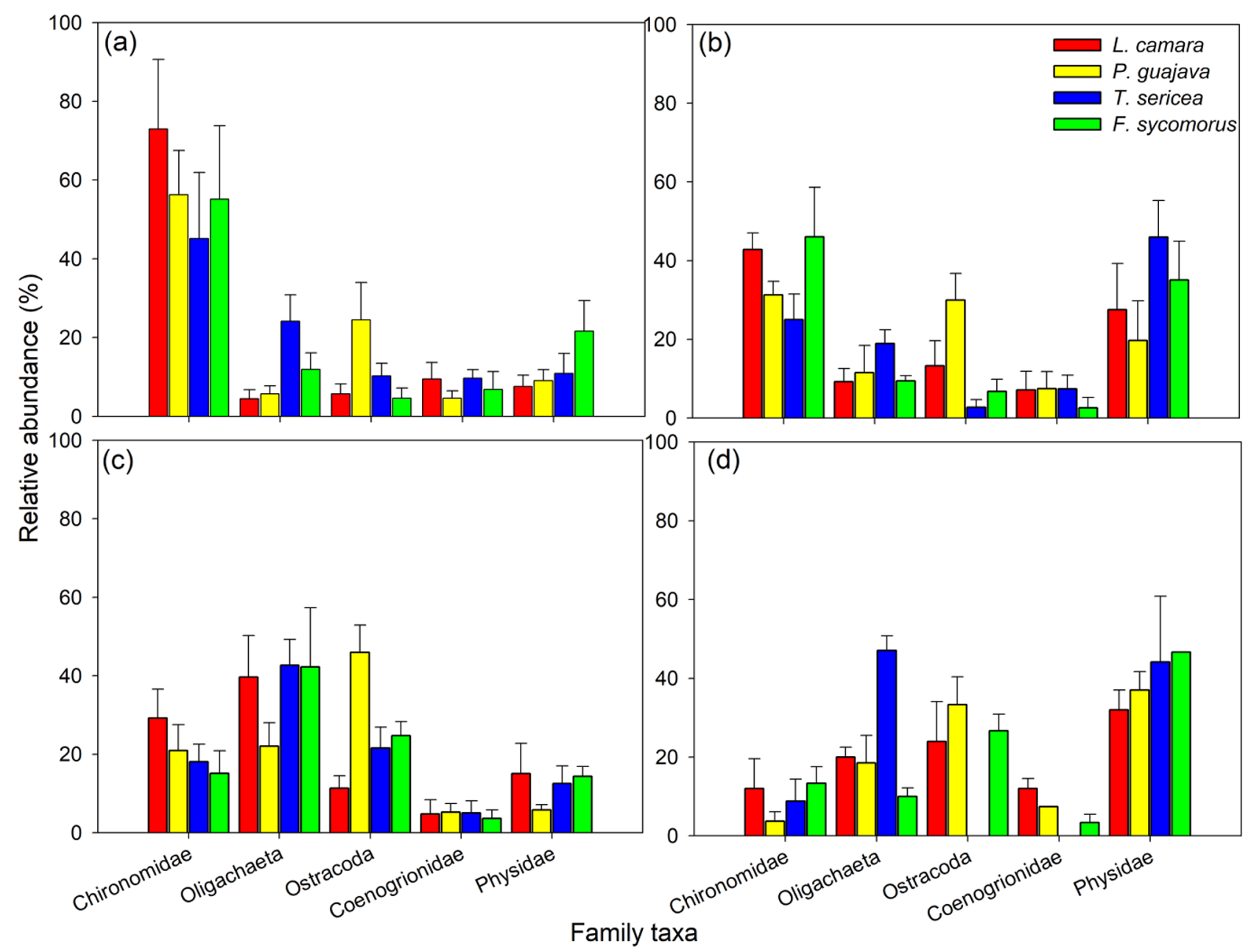

Fig. 2. The colonisation of macroinvertebrates (relative abundance (\%) $\pm \mathrm{SD}$ ) at days 14 (a), 28 (b), 42 (c) and 56 (d) on invasive $L$. camara (red), invasive P. guajava (yellow), native T. sericea (blue) and native F. sycomorus (green).

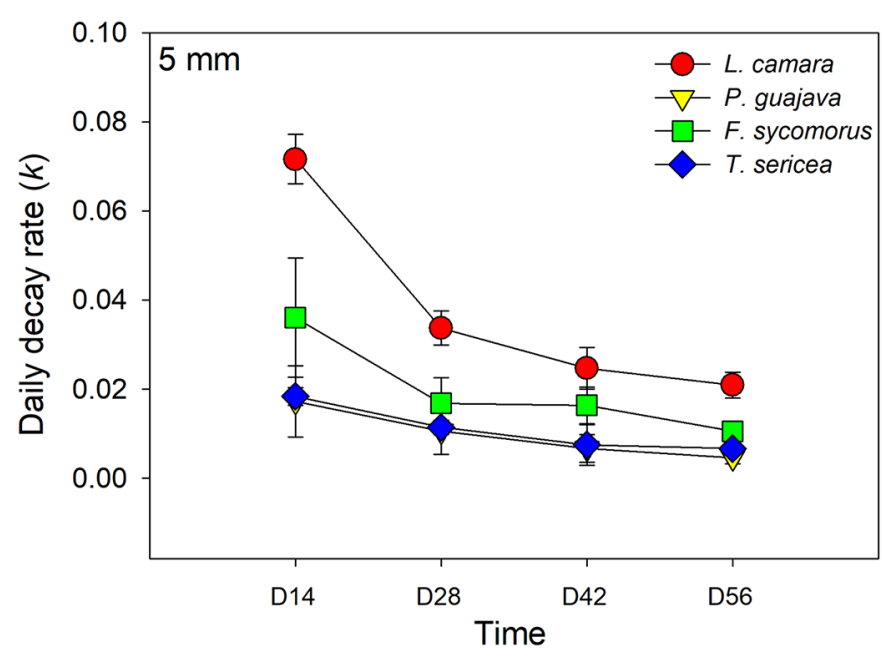

Fig. 3. Decomposition rates $(k)( \pm \mathrm{SD})$ of invasive L. camara (red), invasive P. guajava (yellow), native F. sycomorus (green) and native T. sericea (blue).

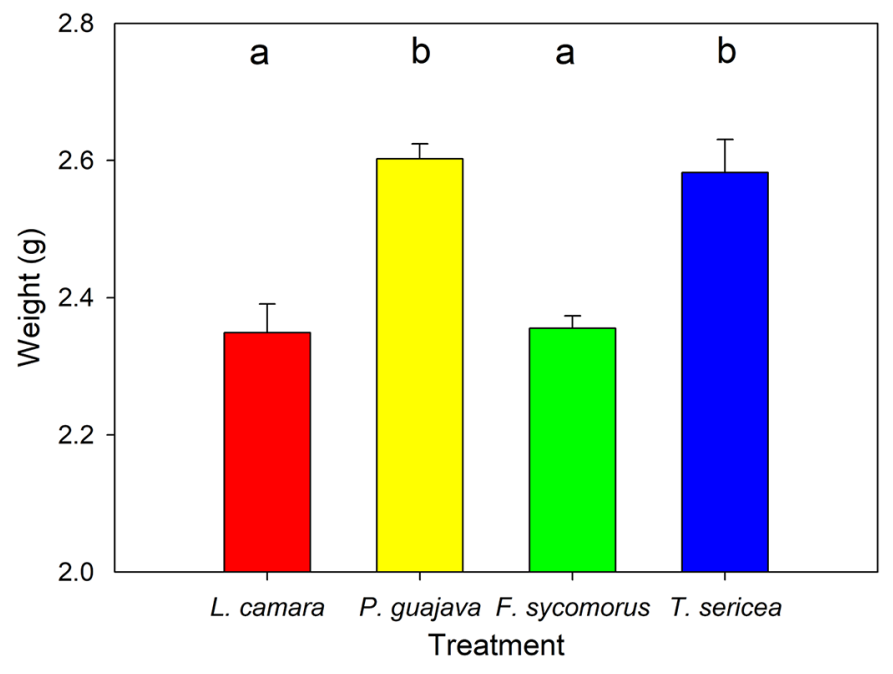

Fig. 4. Mean values $( \pm \mathrm{SD})$ of end-weights of invasive $L$. camara (red), P. guajava (yellow), native F. sycomorus (green) and T. sericea (blue) over $48 \mathrm{hrs}$. Initial weights for all species were $3.0 \mathrm{~g}$ of dried leaf litter. Letters represent pairwise differences. 


\section{Discussion}

In this study, we demonstrate that level of decay of leaf litter can play an important role in determining the abundance of macroinvertebrates by assessing in situ reservoir macroinvertebrate colonisation on four leaf litter treatments. However, responses to leaf litter treatments differed depending on macroinvertebrate group, and generalities according to invasive and native treatment groups were not found. Similarly, decomposition rates did not differ dichotomously between collective invasive and native plants. Our results show that invasive $L$. camara and native $F$. sycomorus decomposed fastest, whilst invasive $P$. guajava and native $T$. sericea leached less. In turn, these decomposition rates likely significantly alter nutrient release dynamics in aquatic environments, with implications for ecosystem structure and function. The decomposition rates were related to the chemistry of unconditioned and conditioned litter.

Both hypotheses of this study were rejected, with abundance of macroinvertebrates and decomposition rates differing among leaf litter types over time at the species grouplevel among invasive and native plants. It was first hypothesised that native $F$. sycomorus and $T$. sericea would support a more abundant invertebrate community compared to invasive $L$. camara and P. guajava, yet abundances tended to differ among macroinvertebrate groups according to specific leaf treatment over time. In turn, no significant effects among invasive and native plant inputs on overall diversity were found. Nevertheless, plant species-specific responses were evidenced, with, for example, L. camara dominated to a greater extent by chironomids, $P$. guajava by ostracods and $T$. sericea by oligochaetes. Second, it was hypothesised that native leaf types would decompose faster than invasive. However, the hypothesis was not supported, with invasive $L$. camara and native $F$. sycomorus decomposing fastest, and invasive $P$. guajava and native $T$. sericea being the slowest. Therefore, there was no clear pattern in leaf decomposition, which occurred at inconsistent rates within and between native and exotic species groupings. It is unlikely that that observed differences in decomposition rates were driven by differences in biotic decomposition processes. Both native and non-native species were readily colonised by macroinvertebrates. Further, Kourtev et al. (2002) highlighted that the microbial community in the litter of two invasive and two native plant species in hardwood forests of New Jersey quickly adapted to litter chemistry differences, and enzyme activity patterns in decomposing litter from the two exotic plant species were virtually indistinguishable between exotic and native locations. As such, it is likely that the observed differences in decomposition rates were rather driven by the quality of the litter (Gundersen et al., 1998).

Differences in macroinvertebrate colonisation of experimental litter bags have been proposed as an indicator of underlying varying rates of leaf decomposition in response to litter quantity (Graça, 2001). A rapid decomposition in leaf litter using mesh bags can be caused by macroinvertebrates and other factors such as temperature (Boulton and Boon 1991), however abiotic effects on decomposition were likely minor in our study given environment parameters did not differ considerably across sampling days or among treatments. However, other factors, such as the C:N, C:P or Lignin:N ratios of the leaf litters were probably different across plant species and likely drove key differences in colonisation and decay. Indeed, Gundersen et al. (1998) highlighted that decomposition and nutrient leaching from plant leaves were related to environmental $\mathrm{C}: \mathrm{N}$ ratios. Moreover, macroinvertebrates responses to leaf litter decomposition differed temporally in the present study, and effects manifested differently among taxonomic groups. Bärlocher (1982) indicated that leaf-eating macroinvertebrates ingest leaf areas rich in fungal cells or leaf matter with high nutritional quality. High feeding activity of a particular leaf type results in faster decomposition since feeding directly results in the breakdown of the litter (Bärlocher, 1982). The rates of decomposition can be thus related to the quality of litter, which in turn relates to physicochemical properties. The highest rate of decomposition was found during the first sampling period of the study, followed by a gradual mass loss for the subsequent 42 days, which indicates two stages of decomposition: an initial stage and an advanced stage (Semwal et al., 2003). In the initial stage, a relatively large decrease in mass was likely observed due to the leaching of readily-soluble substances and non-lignified carbohydrates (Ibrahima et al., 2008). While in the advanced stage, the further decrease in mass loss may be attributed to the release of higher percentage of recalcitrant fractions like cellulose, lignin, and tannin of leaf litter (Nail et al., 2018). Hasanamuzzam and Hossain (2014) highlighted that higher decomposition rates could be an indicator of greater litter quality. Most of the macroinvertebrate functional feeding groups observed within the different treatments were opportunists, as these were not shredders with the exception of chironomids, and were thus not involved in leaf decomposition but could have been feeding on leaf remnants from decomposition, or seeking refuge and/or predating on other organisms (see Braatne et al., 2007). Leroy and Marks (2006) also observed no significant differences in macroinvertebrate colonisation rates among different leaf litter species, with macroinvertebrates varying in diversity and functional feeding groups.

The current study provides an understanding of decomposition and colonisation rates within a changing landscape by assessing native and invasive plants. It is important to understand their colonisation as different macroinvertebrates tolerate different food sources and conditions of aquatic ecosystems and, in turn, act as a food source for other organisms. Furthermore, given that the present study was not carried out in streams/rivers like previous studies (Reice, 1980; Leroy \& Marks, 2006; Boreyo et al., 2011; Santonja et al., 2018), it offers insight into colonisation in reservoir systems within agricultural landscapes, which may be differently affected by human activities. Xiao et al. (2017) and Zeng et al. (2018) highlighted that leaf litter decomposition will be different among individual plant species within reservoirs and that mixing of different plants could facilitate the decomposition of one another, as is the case in natural and artificial systems. Furthermore, Mbaka and Mwaniki (2017) highlighted that reservoirs had a negative effect on litter decomposition and the process was sensitive to reservoir impacts across different river types. Such systems are increasingly common given that streams/rivers continue to be dammed, with numbers of off-stream dams increasing. South Africa, for example, currently has $>50 \quad 000$ small reservoirs and waterbodies that are not naturally connected to streams 
(e.g. irrigation ponds). Accordingly, studies into decomposition rates in these systems, such as ours, are increasingly empirically relevant.

In conclusion, the abundance of macroinvertebrates and the rate of decomposition differed among leaf types over time. Decomposition rates of leaf litter appear not to be a good indicator of the abundance of macroinvertebrates which feed on the leaf since L. camara decomposed faster and generally had low macroinvertebrate abundances, while $F$. sycomorus also decomposed faster and had high abundances. Thus, the decomposition could have been due to microbial and/or fungal breakdown. Further, the leaf types assessed here support higher abundances of Chironomidae, Oligochaeta, Ostracoda and Physidae than Coenogrionidae, however the abundance of macroinvertebrates can be also determined by the size of the mesh bag. Whilst we did not find macroinvertebrate abundances to explicitly relate to invasive status, further research is also needed to investigate decomposition rates of other invasive and native plant species. Moreover, the effects of leaf structure on decomposition and colonisation of macroinvertebrates should be studied to expand the understanding of macroinvertebrate colonisation and the decomposition process.

Acknowledgements. Financial support for this study was granted by the National Research Foundation of South Africa Thuthuka (NRF, UID: 117700) and University of Venda Niche (SES/18/ERM/10) grants to TD. Any opinions, findings, conclusions or recommendations expressed in this material are those of the authors, and the NRF does not accept any liability in this regard. RNC acknowledges funding from the Alexander von Humboldt Foundation.

\section{Conflict of interest}

All authors declare that no conflict of interest exists.

\section{References}

Alonso A, González-Munõz N, Castro-Díez P. 2010. Comparison of leaf decomposition and macroinvertebrate colonization between exotic and native trees in a freshwater ecosystem. Ecol Res 25: 647-653.

Bärlocher F. 1982. Conidium production from leaves and needles in four streams. Can J Bot 60: 1487-1494.

Boreyo L, Pearson RG, Gessner MO, Barmuta LA, Ferreira V, Graca MA, Dudgeon D, Voulton AJ, Callisto M, Chauvet E, Helson JE. 2011. A global experiment suggests climate warming will not accelerate litter decomposition in streams but might reduce carbon sequestration. Ecol Lett 14: 289-294.

Bottollier-Curtet M, Charcosset JY, Planty-Tabacchi AM, Tabacchi E. 2011. Degradation of native and exotic riparian plant leaf litter in a floodplain pond. Freshw Biol 56: 1798-1810.

Boulton AJ, Boon PI. 1991. A review of methodology used to measure leaf litter decomposition in lotic environments: time to turn over an old leaf. Mar Freshw Res 42: 1-43.

Braatne JH, Sullivan SMP, Chamberlain E. 2007. Leaf decomposition and stream macroinvertebrate colonisation of Japanese knotweed, an invasive plant species. Int Rev Hydrobiol 92: 656-665.
Chen Y, Ma S, Jiang H, Yangzom D, Cheng G, Lu X. 2019. Decomposition time, chemical traits and climatic factors determine litter-mixing effects on decomposition in an alpine steppe ecosystem in Northern Tibet. Plant Soil. DOI: 10.1007/ s11104-019-04131-9.

Cummins KW, Merritt RW, Andrade PCN. 2005. The use of invertebrate functional groups to characterize the ecosystem attributes in selected streams and rivers in south Brazil. Stud Neotrop Fauna Environ 40: 69-89.

Dangles O, Malmqvist B. 2004. Species richness-decomposition relationships depend on species dominance. Ecol Lett 7: 395-402.

Duarte S, Pascoal C, Cássio F, Bärlocher F. 2006. Aquatic hyphomycete diversity and identity affect leaf litter decomposition in microcosms. Oecologia 147: 658-666.

Ferreira V, Koricheva J, Pozo J, Graça MAS. 2016. A meta-analysis on the effects of changes in the composition of native forests on litter decomposition in streams. Forest Ecol Manag 364: 27-38.

Gaertner M, Larson BM, Irlich UM, Holmes PM, Stafford L, van Wilgen BW, Richardson DM. 2016. Managing invasive species in cities: a framework from Cape Town, South Africa. Landscape Urban Plan 151: 1-9.

Godoy O, Castro-Díez P, Van Logtestijn RS, Cornelisse JH, Valladares F. 2010. Leaf litter traits of invasive species slow down decomposition compared to Spanish natives: a broad phylogenetic comparison. Oecologia 162: 781-790.

Graça MA. 2001. The role of invertebrates on leaf litter decomposition in streams - a review. Int Rev Hydrobiol 86: 383-393.

Gundersen P, Callesen I, De Vries W. 1998. Nitrate leaching in forest ecosystems is related to forest floor CN ratios. Environ Pollut 102: 403-407.

Henderson L. 2007. Invasive, naturalized and casual alien plants in southern Africa: a summary based on the Southern African Plant Invaders Atlas (SAPIA). Bothalia 37: 215-248.

Ibrahima A, Biyanzi P, Halima M. 2008. Changes in organic compounds during leaf litter leaching: laboratory experiment on eight plant species of the Sudano-guinea Savannas of Ngaoundere, Cameroon. iForest-Biogeosci Forestry 1: 27.

Jeyanny V, Rasidah KW, Husni MA, Kumar BS, Firdaus SM, Arifin A. 2015. Leaf litter decomposition and soil carbon dioxide fluxes across climatic gradient in tropical montane and lowland forests. Journal of Tropical Forest Science 27: 472-487.

Kourtev PS, Ehrenfeld JG, Huang WZ. 2002. Enzyme activities during litter decomposition of two exotic and two native plant species in hardwood forests of New Jersey. Soil Biol Biochem 34: $1207-1218$.

Lenth R. 2019. emmeans: Estimated Marginal Means, aka LeastSquares Means. R package version 1.4.1.

Leroy CJ, Marks JC. 2006. Litter quality, stream characteristics and litter diversity influence decomposition rates and macroinvertebrates. Freshw Biol 51: 606-617.

Mbaka JG, Mwaniki MW. 2017. A critical review of the effect of water storage reservoirs on organic matter decomposition in rivers. Environ Rev 25: 193-198.

Medina-Villar S, Alonso A, Vázquez de Aldana BR, Pérez-Corona E, Castro-Díez P. 2015. Decomposition and biological colonization of native and exotic leaf litter in a Central Spain stream. Limnetica 34: 293-310.

Merritt RW, Cummins KW, Berg MB. 2008. An Introduction to the Aquatic Insects of North America. Duduque, IA, USA: Kendall/ Hunt Publishing Company.

Petersen RC, Cummins KW. 1974. Leaf processing in a woodland stream. Freshw Biol 4: 343-368. 
Pope RJ, Gordon AM, Kaushik NK. 1999. Leaf litter colonization by invertebrates in the littoral zone of a small oligotrophic lake. Hydrobiologia 392: 99-112.

Pothasin P, Compton SG, Wangpakapattanawong P. 2014. Riparian Ficus tree communities: The distribution and abundance of riparian fig trees in Northern Thailand. PloS One 9: 108945.

R Development Core Team. 2018. R: A language and environment for statistical computing. Vienna: R Core Development Team.

Reice SR. 1980. The role of substratum in benthic macroinvertebrates microdistribution and litter decomposition in a woodland stream. Ecology 61: 580-590.

Richardson DM, Van Wilgen BW. 2004. Invasive alien plants in South Africa: how well do we understand the ecological impacts. Working for water. South African J Sci 100: 45-52.

Santonja M, Pellana L, Piscart C. 2018. Macroinvertebrates identity meditates the effects of litter quality and microbial conditioning on leaf litter recycling in temperate streams. Ecol Evol 8: 2542-2553.

Semwal RL, Maikhuri RK, Rao KS, Sen KK, Saxena KG. 2003. Leaf litter decomposition and nutrient release patterns of six multipurpose tree species of central Himalaya, India. Biomass Bioenergy 24: 3-11.

South African Weather Service. 2018. Luvuvhu. Department of Environmental Affairs, Republic of South Africa (online). Available at: www.weathersa.co.za (Accessed September 2018)

Suberkropp K, Chauvet E. 1995. Regulation of leaf breakdown by fungi in streams: influences of water chemistry. Ecology 76: $1433-1445$.

Sunil C, Somashekar RK, Nagaraja BC. 2016. Diversity and composition of riparian vegetation across forest and agroecosystem landscapes of river Cauvery, southern India. Trop Ecol 57: 343-354.

Urquía D, Gutierrez B, Pozo G, Pozo MJ, Espín A, de Lourdes Torres M. 2019. Psidium guajava in the Galapagos Islands: population genetics and history of an invasive species. PLoS One 14: e0203737.

Vardien W, Richardson DM, Foxcroft LC, Thompson GD, Wilson JRU, Le Roux JJ. 2012. Invasion dynamics of Lantana camara L. (sensu lato) in South Africa. South Afr J Bot 81: 81-94.

Wallace JB, Eggert SL, Meyer JL, Webster JR. 2015. Stream invertebrate productivity linked to forest subsidies: 37 stream-years of reference and experimental data. Ecology 96: 1213-1228.

Wallace KJ. 2012. Values: drivers for planning biodiversity management. Environ Sci Policy 17: 1-11.

Webster JR, Benfield EF. 1986. Vascular plant breakdown in freshwater ecosystems. Annu Rev Ecol Syst 17: 567-594.

Whittaker RH. 1977. Evolution of species diversity in land communities. Evol Biol 10: 1-67.

Xiao L, Zhu B, Kumwimba MN, Jiang S. 2017. Plant soaking decomposition as well as nitrogen and phosphorous release in the water-level fluctuation zone of the Three Gorges Reservoir. Sci Total Environ 592: 527-534.

Zeng L, He W, Teng M, Luo X, Yan Z, Huang Z, Zhou Z, Wang P, Xiao W. 2018. Effects of mixed leaf litter from predominant afforestation tree species on decomposition rates in the Three Gorges Reservoir, China. Sci Total Environ 639: 679-686.

Zuur AF, Ieno EN, Elphick CS. 2010. A protocol for data exploration to avoid common statistical problems. Methods Ecol Evol 1: $3-14$.

Cite this article as: Mutshekwa T, Cuthbert RN, Wasserman RJ, Murungweni FM, Dalu T. 2020. Macroinvertebrate colonisation associated with native and invasive leaf litter decomposition. Knowl. Manag. Aquat. Ecosyst., 421, 32. 